\title{
THE LOAD DEPENDENCE OF THE MICRO-HARDNESS OF THE BLAST FURNACE SLAG
}

\author{
Jozef Petrík *, Peter Blaško, Vojtech Mikloš, Alena Pribulová, Peter Futaš, \\ Andrea Vasilňaková, Marek Šolc
}

Technical University of Košice, Faculty of Materials, Metallurgy and Recycling, 042 00, Slovakia

Received 08.06.2020

Accepted 10.09.2020

\begin{abstract}
Deposits of old blast-furnace slag are an environmental problem. The slag's hardness is an important for calculation of the energy cost for crushing and grinding process. Due to its porosity, the measurement of (macro) hardness must be adapted so that the indentation dimensions are suited to the character of the slag. Thus, it is necessary to apply loads in the range of micro-hardness. The purpose of this paper is to evaluate the influence of load on the micro-hardness - the Indentation Size Effect (ISE) using Meyer's, Hays-Kendall and PSR methods. ISE for all samples is "normal", the slag's basicity affects micro-hardness and ISE.
\end{abstract}

Keywords: grinding; iron slag; ISE; micro-hardness.

\section{Introduction}

Since the $18^{\text {th }}$ century, large plants with several blast furnaces produced enormous amounts of slag. According to data published by Ling et al. [1], the annual production of granulated blast furnace slag in China is around 15 million tons. About 17 million tons of iron and steel slags (1:1) were sold in 2011 in the USA [2]. The worldwide pig iron and steel slag production, as estimated by Kalyoncu [3], was approximately 200 million tons in 2000 .

Because the dumping of the slag has a potentially undesirable impact on the environment, it is advisable to recover metals from the slags and utilize them in other ways. As demonstrated Veselská \& Majzlan [4], the layers of old iron slag are generally not dangerous with regard to possible toxicity. However, they are dangerous due to the unstable subsoil. It was found that the radioactivity of iron slag in Slovakia [5, 6] and in Romania [7] does not exceed the limit permitted by the legislation.

${ }^{*}$ Corresponding author: Jozef Petrík, jozef.petrik@tuke.sk 
Nevertheless, the slag can be used as secondary raw material for the manufacturing of "slag" bricks, mineral wool, floor tiles, or winter road sanding. The largest amount of the steel slag is used in the construction industry as support slag gravel in road-building and filler material in construction work of railway embankments [8]. In some cases, the slag may contain metals that can be recovered secondarily. Bulut reported about 2.5 million tonnes of copper slag available in Küre, Turkey contains copper $(0.98 \%)$, cobalt $(0.49 \%)$ and iron $(51.47 \%)$ [9].

The blast furnace slag is generally processed by conventional crushing and grinding equipment. According to Li et al. [10] and User Guidelines for Waste and Byproduct Materials [11], crushed air-cooled blast furnace slag is angular, roughly cubical, its textures ranging from rough, vesicular surfaces to glassy, smooth surfaces with conchoidal.

The hardness of the slag is an important feature for the calculation of energy cost in the crushing or grinding process. The grindability depends on the bulk characteristics, such as fractions of coarse and fine slag, as well as intrinsic characteristics, such as the hardness $[5,12]$.

Betrancourt at al. [13] published that due to pores or defects encountered by the indenter during its penetration into the material (pop - in phenomenon), measurement of the (macro) hardness of the slag can be complicated, and the results may not be reliable.

The Vickers test is often used for micro-measurement, as it is suitable for hard materials such as the slag. In the literature, different loads are used to measure the microhardness of the slag: the load $1.96 \mathrm{~N}$ used, for example, Michalíková et al. [5], Wang [14] and Liu et al. [15]; the load $0.98 \mathrm{~N}$ preferred Ilyushechkin et al. [12].

The Vickers micro-hardness test is identical to the macro test, except for a smaller applied load. The advantage of the Vickers test is the (macro) hardness independence of the load; on the contrary, the micro-hardness depends on it $[16,17]$. This phenomenon is known as the indentation size effect (ISE).

Several authors found that if a very low load is used, the measured micro-hardness is high; with an increase in the load, the measured micro-hardness decreases [18, 19]. There is a "normal" ISE, whose causes were summarized, i.e. Petrík [20] under the authority of, i.e. Sangwal et al. [18], Gong et al. [21], Ren et al. [22]. In the literature, there are many examples which reveal that the "normal" ISE occurs in brittle materials.

In contrast to "normal" ISE, a reverse type of ISE (RISE) is where the microhardness increases with increasing load, is also known. The RISE essentially takes place in materials in which plastic deformation is predominant.

The purpose of this paper is to evaluate the influence of load on the micro-hardness measured on glassy "acid" blast furnace slag using Meyer's, Hays - Kendall, and PSR methods.

\section{Materials and Methods}

The experimental material is the slag of iron smelting in charcoal blast furnaces. Samples were found in the territory of Slovakia. The "Slovak furnace" (Windische Ofen) - the bloomery operated by water power was the dominant equipment until the middle of the $19^{\text {th }}$ century. The defensive war against the Osman Empire (1541-1685), repeated rebellions against the absolutist rule of the Hapsburg dynasty (1605-1711), and the conservatism of the enterprisers caused the lag in the blast furnace process; the first blast furnace was built only in 1692. The iron metallurgy in Slovakia reached its peak in the 
middle of the 1870s (59 ironworks with blast furnaces); only two blast furnaces are in operation today.

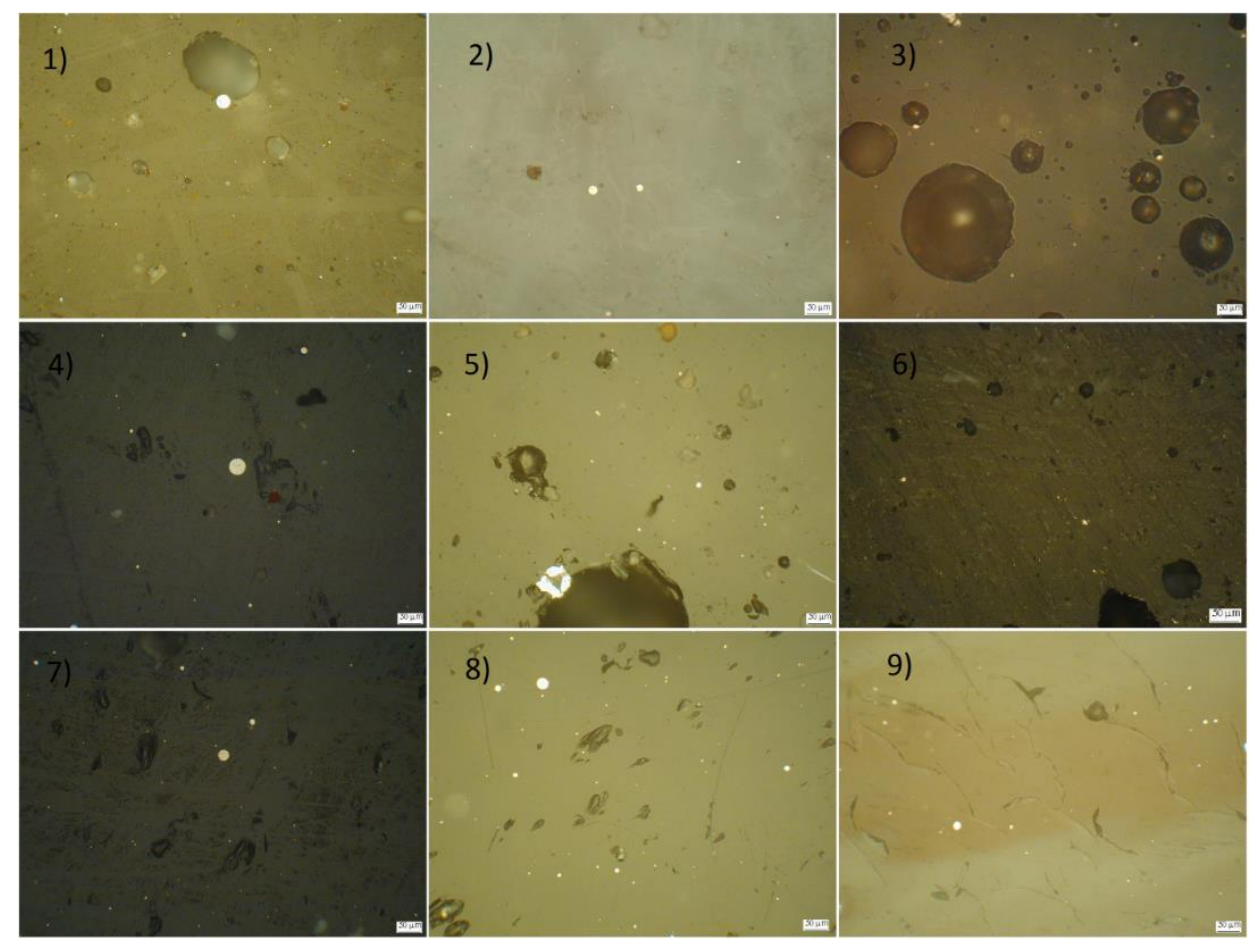

Fig. 1. The microstructure of analyzed slags, the light round particles, are unetched iron.

A list of analysed slags is in Table 1 . Their microstructure generally consists of fayalite $\left(\mathrm{Fe}_{2} \mathrm{SiO}_{4}\right)$ with globular iron particles, pores, blows, and cracks. Typical microstructures of analyzed slags are in Fig. 1; for example, the slag No. 2 (Remetské Hámre) with diopside is in cell 2). The samples are numbered in accordance with Table 1. X-ray analysis of crystalline phases, slags of Lúčka, Jakubany, and Henckovce, shows Fig. 2. 


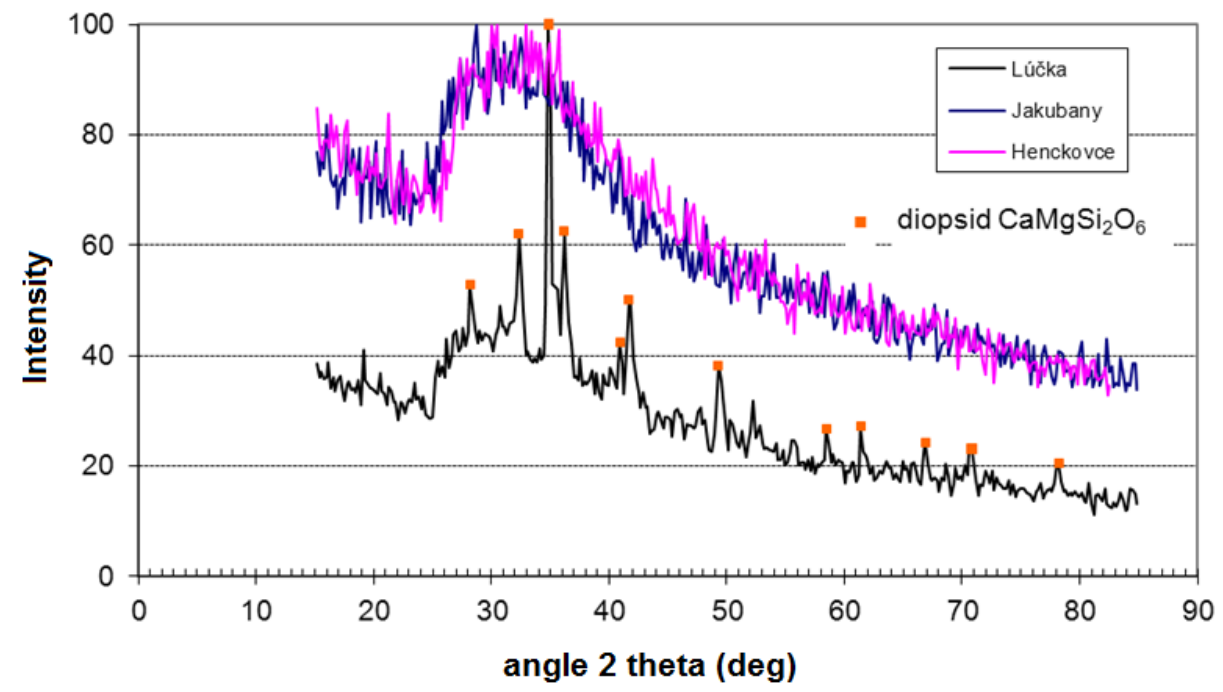

Fig. 2. X-ray analysis of crystalline phases, slags of Lúčka, Jakubany, and Henckovce.

Table 1. Analysed slags: (locality, geographical coordinates, the period of the operation, and the shape).

\begin{tabular}{|c|c|c|c|c|c|}
\hline No. & locality & $\mathrm{N}$ & $\mathrm{E}$ & $\begin{array}{l}\text { operated } \\
\text { between }\end{array}$ & shape \\
\hline 1 & $\begin{array}{l}\text { Zemplínske } \\
\text { Hámre }\end{array}$ & $48^{\circ} 56^{\prime} 58^{\prime}$ & $22^{\circ} 09^{\prime} 19^{\prime \prime}$ & $1815-1873$ & $\begin{array}{l}\text { glassy, grey- } \\
\text { green }\end{array}$ \\
\hline 2 & $\begin{array}{l}\text { Remetské } \\
\text { Hámre }\end{array}$ & $48^{\circ} 50^{\prime} 51^{\prime \prime}$ & $22^{\circ} 11^{\prime} 02^{\prime \prime}$ & $1780-1922$ & $\begin{array}{l}\text { glassy, } \\
\text { green }\end{array}$ \\
\hline 3 & Osrblie & $48^{\circ} 43^{\prime} 34^{\prime}$, & $19^{\circ} 30^{\prime} 13^{\prime \prime}$ & $1795-1873$ & $\begin{array}{l}\text { turquoise, grey- } \\
\text { blue }\end{array}$ \\
\hline 4 & Sirk & $48^{\circ} 36^{\prime} 15^{\prime \prime}$ & $20^{\circ} 06^{\prime} 32^{\prime \prime}$ & $1871-1903$ & glassy, black \\
\hline 5 & Drnava & $48^{\circ} 38^{\prime} 25^{\prime}$ & $20^{\circ} 29^{\prime} 33^{\prime \prime}$ & $1830-1913$ & glassy black \\
\hline 6 & Cinobaňa & $48^{\circ} 27^{\prime} 21^{\prime \prime}$ & $19^{\circ} 38^{\prime} 30^{\prime \prime}$ & $1847-1860$ & $\begin{array}{l}\text { glassy, cobalt- } \\
\text { blue }\end{array}$ \\
\hline 7 & Jakubany & $49^{\circ} 13^{\prime} 02^{\prime}$, & $20^{\circ} 40^{\prime} 56^{\prime \prime}$ & $1776-1860$ & glassy, black \\
\hline 8 & Lúčka & $48^{\circ} 37^{\prime} 59^{\prime \prime}$ & $20^{\circ} 43^{\prime} 06^{\prime \prime}$ & $1853-1903$ & glassy grey \\
\hline 9 & Henckovce & $48^{\circ} 42^{\prime} 50^{\prime \prime}$ & $20^{\circ} 25^{\prime} 58^{\prime \prime}$ & $1852-1903$ & $\begin{array}{l}\text { green, } \\
\text { laminated }\end{array}$ \\
\hline
\end{tabular}


Samples were cut by cooled diamond saw ground with dry SiC sandpaper $(220 \rightarrow$ 3000ANSI/CAMI grit) and polished with diamond paste $(1 \mu \mathrm{m})$. The rest of the sample was pulverised and analysed by AAS PERKIN ELMER 3100, and by spectrometer Niton XL3 Goldd, the results are in Table 2 . The presence of secondary ( $1-0.001 \%$, bold type) and trace (0.01-0.00001\%) elements was determined by spectrograph PGS-2. The crystalline phases were identified by X-ray powder diffractometer DRON 3-M (Co K $\alpha$ radiation, $30 \mathrm{kV}, 25 \mathrm{~mA}$ ). The glassy fayalite is the base of all samples. It is supplemented with quartz, wollastonite, magnetite, and hematite in the slag No. 1 (Zemplínske Hámre) and with diopside in slags No. 8 (Lúčka), Fig. 2, and No. 2 (Remetské Hámre). Phase diagrams of other slags are similar to slag No. 7 (Jakubany), Fig. 2.

The Vickers micro-hardness was measured by Hanemann tester, type Mod D32 fitted to microscope Neophot-32. A reference block with specified hardness $H_{c}=519$ HV0.05 and standard uncertainty $\mathrm{u}_{\mathrm{CRM}}=6.75 \mathrm{HV} 0.05$ was used for the calibration of the tester according to the standard ISO 6507-2 [23]; the tester has met its requirements $\left(\mathrm{r}_{\text {rel }}\right.$ $=4.65 \%, \mathrm{E}_{\text {rel }}=-1.31 \%$ and $\left.\mathrm{U}_{\text {rel }}=6.32 \%\right)$.

Table 2. Composition of analysed slag and compared specimens (in wt. \%), and estimated production of the slag in the ironworks.

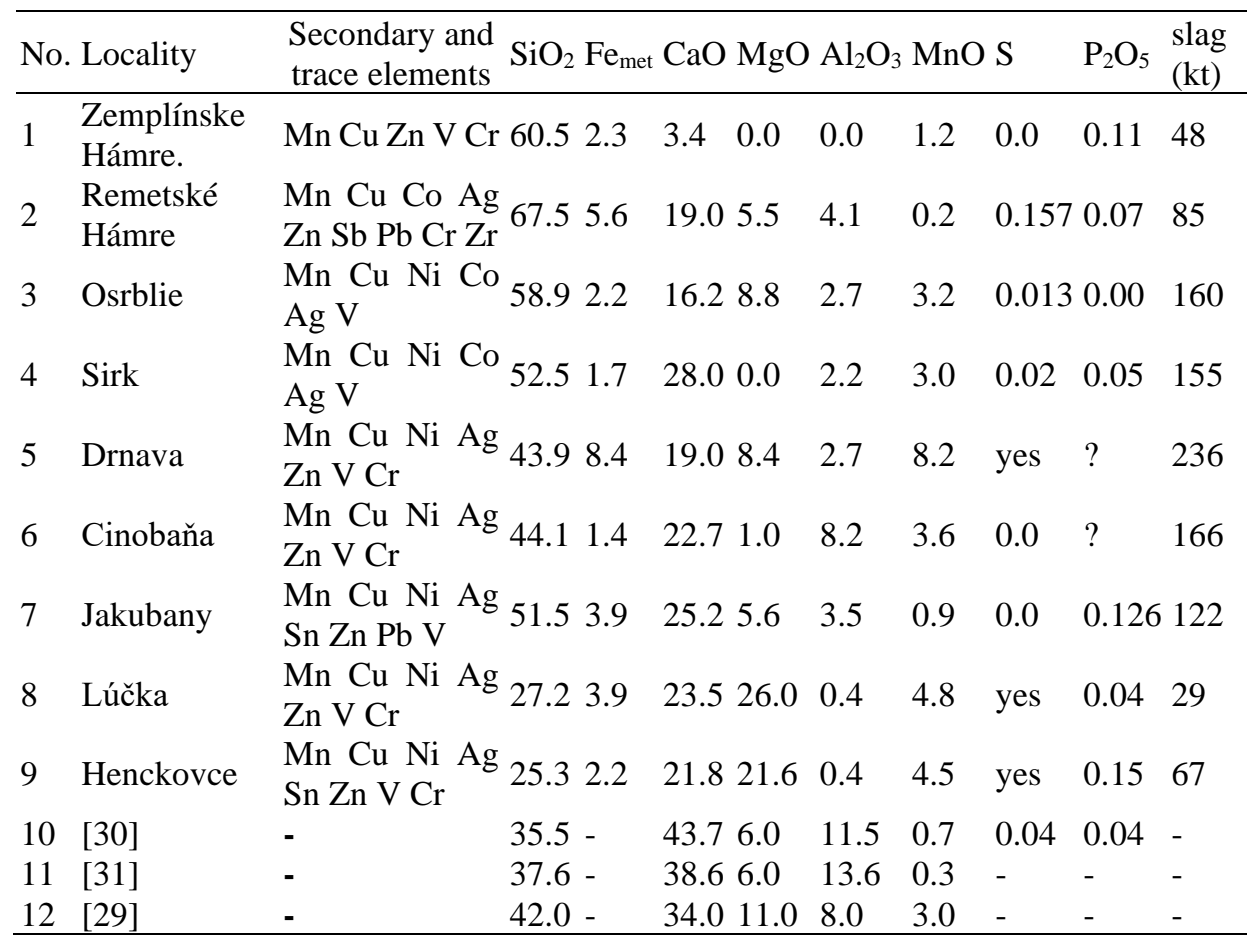

As regards the measurement of the micro-hardness, five indentations were done at each load P between $0.09807 \mathrm{~N}$ and $0.9807 \mathrm{~N}$ in step $0.09807 \mathrm{~N}$ with the load duration $15 \mathrm{~s}$ and the average speed of the indenter's penetration $1.0 \mu \mathrm{m} / \mathrm{s}$. The "measurement" is a file of 50 values. The values of micro-hardness are in Fig. 3. 
The normality and outliers of individual "measurements" were calculated by Grubbs' test (significance level $\alpha=0.05$ ) and by Anderson - Darling test, $p>0.05$ for the "measurement" with a normal distribution. The average micro-hardness HV of the "measurement", micro-hardness HV0.05, normality ( $\mathrm{p}$ - value), outliers, and relative expanded uncertainty of micro-hardness HV0.05 $\mathrm{U}_{\text {rel }}$ calculated according to standard, ISO 6507-1 [24], are in Table 3.

Table 3. The micro-hardness - the average value of all 50 indentations (HV), microhardness HV0.05, outliers, test of normality ( $p$ value), and relative expanded uncertainty of micro-hardness $\mathrm{HV} 0.05 \mathrm{U}_{\text {rel }}$.

\begin{tabular}{lllllll}
\hline & Locality & HV & HV0.05 & outliers & p-value & $\mathrm{U}_{\text {rel }}(\%)$ \\
\hline 1 & Zemplínske Hámre & 838 & 676 & 0 & 0.0 & 11.3 \\
2 & Remetské Hámre & 711 & 685 & 3 & 0.0 & 7.2 \\
3 & Osrblie & 873 & 947 & 1 & 0.01557 & 11.0 \\
4 & Sirk & 777 & 773 & 0 & 0.45668 & 7.6 \\
5 & Drnava & 835 & 727 & 6 & 0.0 & 6.9 \\
6 & Cinobaňa & 1168 & 1228 & 1 & 0.00124 & 15.0 \\
7 & Jakubany & 924 & 744 & 3 & 0.0 & 9.2 \\
8 & Lúčka & 722 & 676 & 5 & 0.0 & 10.7 \\
9 & Henckovce & 866 & 855 & 1 & 0.00276 & 11.3 \\
\hline
\end{tabular}

\section{Theory and calculation}

Meyer's power law, proportional specimen resistance (PSR), and Hays - Kendall approach were used for the quantitative description of the ISE. The procedure for calculating ISE characteristics using references of Sangwal et al. [18], Li \& Bradt [25] and Michels \& Frischat [26], and in particular, the procedure of the measuring the ceramic micro-hardness by Kim \& Kim [27] presented in more detail Petrík [20].

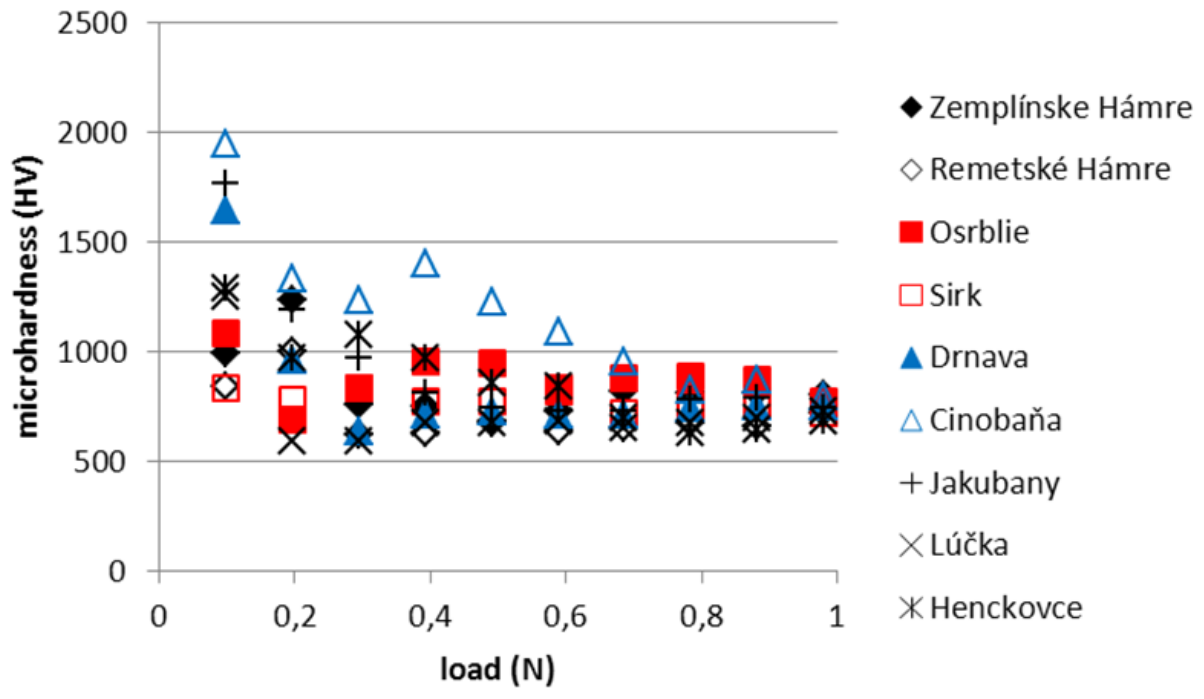

Fig. 3. The relationship between load and micro-hardness. 
Meyer's Law described by equation (1), is the simplest way to describe the ISE:

$$
P=A n^{d}
$$

Meyer's index $\mathrm{n}$ or work hardening coefficient is the slope, and $\mathrm{A}_{\ln }$ is the $\mathrm{y}$ intercept of the straight line graph of $\ln (\mathrm{d})$ versus $\ln (\mathrm{P}) ; \mathrm{d}(\mathrm{mm})$ is the diagonal of indentation, and $\mathrm{P}(\mathrm{N})$ is applied load. For "normal "ISE $\mathrm{n}<2$, for reverse ISE $\mathrm{n}>2$ and $\mathrm{n}=2$ is given by Kick's Law for the load independent micro-hardness.

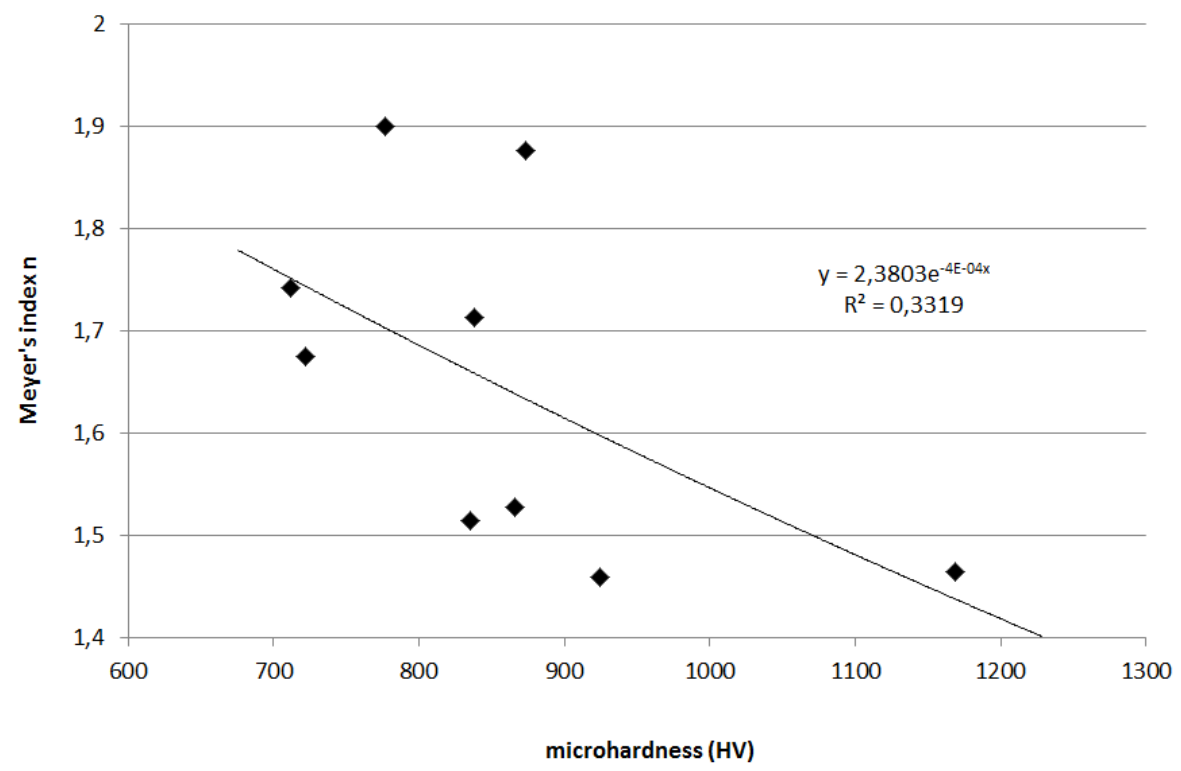

Fig. 4. The relationship between the micro-hardness $H V$ and Meyer's index $n$.

Values of indices $n$ and $A_{\ln }$ are listed in Table 4. As can be seen in Fig. 4, the value of $n$ decreases (with a tendency towards a more pronounced ISE) with increasing microhardness of the slag. 
Table 4. The values of indices for Meyer's, PSR and Hays-Kendall methods and "true hardness".

\begin{tabular}{|c|c|c|c|c|c|c|c|c|c|c|c|c|}
\hline \multirow{2}{*}{$\begin{array}{l}\text { Meth } \\
\text { od } \\
\text { Samp } \\
\text { le/ } \\
\text { index }\end{array}$} & \multicolumn{2}{|c|}{ Meyer } & \multicolumn{2}{|c|}{ PSR } & \multicolumn{3}{|c|}{ Modified PSR } & \multicolumn{2}{|c|}{$\begin{array}{l}\text { Hays- } \\
\text { Kendall }\end{array}$} & \multicolumn{3}{|c|}{$\begin{array}{l}\text { "True } \\
\text { hardness } \\
\text { "H }\end{array}$} \\
\hline & $\mathrm{n}$ & $\mathrm{A}_{\ln }$ & $\mathrm{a}_{1}$ & $\mathrm{a}_{2}$ & $\mathrm{c}_{0}$ & $\mathrm{c}_{1}$ & $\mathrm{c}_{2}$ & W & $\mathrm{A}_{1}$ & $a_{2}$ & $\mathrm{c}_{2}$ & $\mathrm{~A}_{1}$ \\
\hline 1 & $\begin{array}{l}1.71 \\
29\end{array}$ & $\begin{array}{l}7.0 \\
6\end{array}$ & $\begin{array}{l}8.6 \\
3\end{array}$ & $\begin{array}{l}344 \\
7\end{array}$ & $\begin{array}{l}0.2 \\
18\end{array}$ & $\begin{array}{l}- \\
47 . \\
59\end{array}$ & $\begin{array}{l}647 \\
0\end{array}$ & $\begin{array}{l}0.0 \\
13\end{array}$ & $\begin{array}{l}4070 \\
.9\end{array}$ & $\begin{array}{l}65 \\
2\end{array}$ & $\begin{array}{l}122 \\
3\end{array}$ & $\begin{array}{l}77 \\
0\end{array}$ \\
\hline 2 & $\begin{array}{l}1.74 \\
27\end{array}$ & $\begin{array}{l}7.0 \\
6\end{array}$ & $\begin{array}{l}6.9 \\
6\end{array}$ & $\begin{array}{l}302 \\
9\end{array}$ & $\begin{array}{l}0.1 \\
81\end{array}$ & $\begin{array}{l}- \\
35 . \\
67\end{array}$ & $\begin{array}{l}513 \\
6\end{array}$ & $\begin{array}{l}0.0 \\
12\end{array}$ & $\begin{array}{l}3486 \\
.3\end{array}$ & $\begin{array}{l}57 \\
3\end{array}$ & 971 & $\begin{array}{l}65 \\
9\end{array}$ \\
\hline 3 & $\begin{array}{l}1.87 \\
55\end{array}$ & $\begin{array}{l}7.8 \\
5\end{array}$ & $\begin{array}{l}4.4 \\
3\end{array}$ & $\begin{array}{l}411 \\
0\end{array}$ & $\begin{array}{l}- \\
0.1 \\
04\end{array}$ & $\begin{array}{l}28 . \\
87\end{array}$ & $\begin{array}{l}284 \\
5\end{array}$ & $\begin{array}{l}0.0 \\
30\end{array}$ & $\begin{array}{l}4248 \\
.6\end{array}$ & $\begin{array}{l}77 \\
7\end{array}$ & 538 & $\begin{array}{l}80 \\
3\end{array}$ \\
\hline 4 & $\begin{array}{l}1.89 \\
95\end{array}$ & $\begin{array}{l}7.8 \\
6\end{array}$ & $\begin{array}{l}4.7 \\
4\end{array}$ & $\begin{array}{l}362 \\
2\end{array}$ & $\begin{array}{l}- \\
0.0 \\
70\end{array}$ & $\begin{array}{l}20 . \\
73\end{array}$ & $\begin{array}{l}282 \\
3\end{array}$ & $\begin{array}{l}0.0 \\
30\end{array}$ & $\begin{array}{l}3785 \\
.5\end{array}$ & $\begin{array}{l}68 \\
5\end{array}$ & 534 & $\begin{array}{l}71 \\
6\end{array}$ \\
\hline 5 & $\begin{array}{l}1.51 \\
44\end{array}$ & $\begin{array}{l}6.1 \\
3\end{array}$ & $\begin{array}{l}12 . \\
90\end{array}$ & $\begin{array}{l}287 \\
7\end{array}$ & $\begin{array}{l}0.1 \\
63\end{array}$ & $\begin{array}{l}- \\
34 . \\
04\end{array}$ & $\begin{array}{l}548 \\
6\end{array}$ & $\begin{array}{l}0.0 \\
17\end{array}$ & $\begin{array}{l}3793 \\
.2\end{array}$ & $\begin{array}{l}54 \\
4\end{array}$ & $\begin{array}{l}103 \\
7\end{array}$ & $\begin{array}{l}71 \\
7\end{array}$ \\
\hline 6 & $\begin{array}{l}1.46 \\
46\end{array}$ & $\begin{array}{l}6.1 \\
4\end{array}$ & $\begin{array}{l}27 . \\
65\end{array}$ & $\begin{array}{l}259 \\
8\end{array}$ & $\begin{array}{l}- \\
0.1 \\
13\end{array}$ & $\begin{array}{l}60 . \\
15\end{array}$ & 727 & $\begin{array}{l}0.1 \\
35\end{array}$ & $\begin{array}{l}3823 \\
.9\end{array}$ & $\begin{array}{l}49 \\
1\end{array}$ & 137 & $\begin{array}{l}72 \\
3\end{array}$ \\
\hline 7 & $\begin{array}{l}1.45 \\
96\end{array}$ & $\begin{array}{l}5.9 \\
5\end{array}$ & $\begin{array}{l}19 . \\
26\end{array}$ & $\begin{array}{l}255 \\
9\end{array}$ & $\begin{array}{l}0.1 \\
02\end{array}$ & $\begin{array}{l}- \\
9.4 \\
9\end{array}$ & $\begin{array}{l}414 \\
3\end{array}$ & $\begin{array}{l}0.0 \\
63\end{array}$ & $\begin{array}{l}3665 \\
.3\end{array}$ & $\begin{array}{l}48 \\
4\end{array}$ & 783 & $\begin{array}{l}69 \\
3\end{array}$ \\
\hline 8 & $\begin{array}{l}1.67 \\
55\end{array}$ & $\begin{array}{l}6.7 \\
5\end{array}$ & $\begin{array}{l}4.9 \\
3\end{array}$ & $\begin{array}{l}321 \\
5\end{array}$ & $\begin{array}{l}0.1 \\
58\end{array}$ & $\begin{array}{l}- \\
37 . \\
04\end{array}$ & $\begin{array}{l}543 \\
5\end{array}$ & $\begin{array}{l}- \\
0.0 \\
14\end{array}$ & $\begin{array}{l}3698 \\
.1\end{array}$ & $\begin{array}{l}60 \\
8\end{array}$ & $\begin{array}{l}102 \\
8\end{array}$ & $\begin{array}{l}69 \\
9\end{array}$ \\
\hline 9 & $\begin{array}{l}1.52 \\
76\end{array}$ & $\begin{array}{l}6.2 \\
3\end{array}$ & $\begin{array}{l}21 . \\
31\end{array}$ & $\begin{array}{l}223 \\
0\end{array}$ & $\begin{array}{l}- \\
0.0 \\
91\end{array}$ & $\begin{array}{l}44 . \\
29\end{array}$ & $\begin{array}{l}105 \\
8\end{array}$ & $\begin{array}{l}0.1 \\
15\end{array}$ & $\begin{array}{l}3093 \\
.5\end{array}$ & $\begin{array}{l}42 \\
2\end{array}$ & 200 & $\begin{array}{l}58 \\
5\end{array}$ \\
\hline
\end{tabular}

The proportional specimen resistance model of $\mathrm{Li} \&$ Bradt (PSR) is practically a modified Hays/Kendall approach. Several authors, as Gong et al. [21] and Li \& Bradt [25] have proposed that the "normal" ISE behaviour can be described by equation (2):

$$
\frac{P}{d}=a_{1}+a_{2} d
$$

Indices $\mathrm{a}_{1}(\mathrm{~N} / \mathrm{mm})$ and $\mathrm{a}_{2}(\mathrm{~N} / \mathrm{mm})$ are related to the elastic and plastic properties of the material, respectively [27]. Index $\mathrm{a}_{1}$ is connected with the dependence of microhardness on the load; harder materials as a slag generally have higher $\mathrm{a}_{1}$ values. 


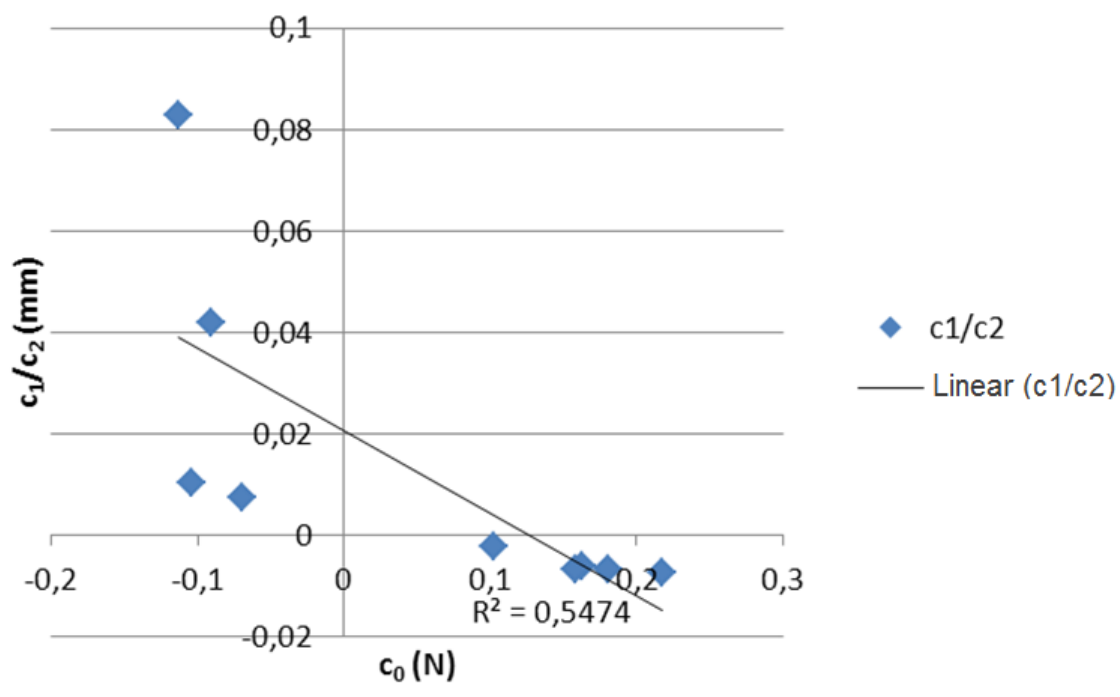

Fig. 5. The relationship between $c_{0}$ and $c_{1} / c_{2}$.

Gong et al. [21] presented that the index $\mathrm{a}_{2}$ is associated with load-independent "true hardness "HPSR, calculated by equation (3).

$$
H_{\text {PSRa2 }}=0.1891 \times a_{2}
$$

Indices $\mathrm{A}_{1}$ or $\mathrm{c}_{2}$ also can be used; values of "true hardness "are in Table 4. Equation (4) is a modified form of the PSR model.

$$
P=c_{0}+c_{1} d+c_{2} d^{2}
$$

The index $\mathrm{c}_{0}(\mathrm{~N})$ is associated with residual surface stress, and indices $\mathrm{c}_{1} \sim \mathrm{a}_{1}$ and $\mathrm{c}_{2} \sim \mathrm{a}_{2}$ are related, respectively, with the elastic and plastic properties, Table 4 .

The ratio $c_{1} / c_{2}$ is a measure of the stresses due to machining and polishing of the sample. The expected relationship between $c_{0}$ and $c_{1} / c_{2}$, was achieved only after the elimination of the hardest slag (No. 6), Fig. 5.

Hays and Kendall proposed the existence of minimum test load W $(\mathrm{N})$ necessary to initiate plastic deformation - visible indentation. Below it, only elastic deformation occurs. It is expressed by equation (5).

$$
P=W+A_{1} d^{2}
$$

Where $A_{1}\left(\mathrm{~N} / \mathrm{mm}^{2}\right)$ is an index independent of load, Table 4.

\section{Results and discussion}

Pure metals (Al, Zn, Cu, Fe, Ni, Co) tested at loads between $0.09807 \mathrm{~N}$ and 0.9807 $\mathrm{N}$ show "reverse "ISE [28]. Particles of mullite $\left(3 \mathrm{Al}_{2} \mathrm{O}_{3} \cdot 2 \mathrm{SiO}_{2}\right)$ may occur in blast furnace slags, and their hardness is about $7 \mathrm{GPa}(700 \mathrm{HV})$ with low dependence on an applied load ( $\mathrm{n}=1.979)$; according to Gong et al. [21], the ISE in mullite is negligible. The microhardness of the slag with chemical composition listed in Table 2 (sample No. 12) ranges 
between 3.75 - $7.25 \mathrm{GPa}(375-725 \mathrm{HV})$ depending up a final heating temperature and soaking period [29]. As presented Fredericci [30], the micro-hardness of the slag (sample No. 10 in Table 2) is $5.2 \pm 0.4 \mathrm{GPa}(520 \pm 40 \mathrm{HV})$ at load $0.4903 \mathrm{~N}$ and of the slag (sample No. 11 in Table 2) is $8.4 \mathrm{GPa}(840 \mathrm{HV})$ at load $1 \mathrm{~N}$. According to what Ostrowski \& Rzechula [31] and Liu et al. [15] reported the blast furnace slag with basicity $\mathrm{CaO} / \mathrm{SiO}_{2}$ $=0.4$ and $\sim 10$ wt. $\% \mathrm{Al}_{2} \mathrm{O}_{3}$ has micro-hardness of $6.2 \mathrm{GPa}(620 \mathrm{HV})$ at load $1.96 \mathrm{~N}$. These examples illustrate the measurement of micro-hardness of slags in practice. However, the results are rarely published, and the study focusing on the load influence on the micro-hardness, is scarce.

The basicity B of the slags was calculated by equation (6).

$$
B=\frac{\mathrm{CaO}+\mathrm{MgO}}{\mathrm{SiO}_{2}+\mathrm{P}_{2} \mathrm{O}_{5}}(\% w t .)
$$

With increasing of basicity, the micro-hardness and the value of Meyer's index n moderately decreases (toward to "normal" values). The drop in "true hardness" is more pronounced, Fig. 6.

The present blast furnace slag is basic. Greater porosity and inhomogeneity of basic slag (more or less homogeneous fayalite is replaced by a mixture of wollastonite, gehlenite, melilite, merwinite, rankinite, or monticellite) will complicate the measurement.

Microstructure (also with an indication of the presence of further phases in the glass matrix of samples No. 2 and 8) and crystalline phases (wollastonite in sample No. 1 and diopside in samples No. 2 and 8) have not a significant impact on the microhardness and ISE. Because there are differences in micro-hardness of wollastonite (5.6 $\mathrm{GPa}$ at load $2.495 \mathrm{~N})$, stated by Teixeira et al. [32], diopside (7.0 - 8.8 GPa at load 0.5 N) stated by Smedskjaer et al. [33], and fayalite (6.0 GPa at $0.495 \mathrm{~N})$ stated by Takeda et al. [34], the more pronounced effect of these crystalline phases on micro-hardness was expected.

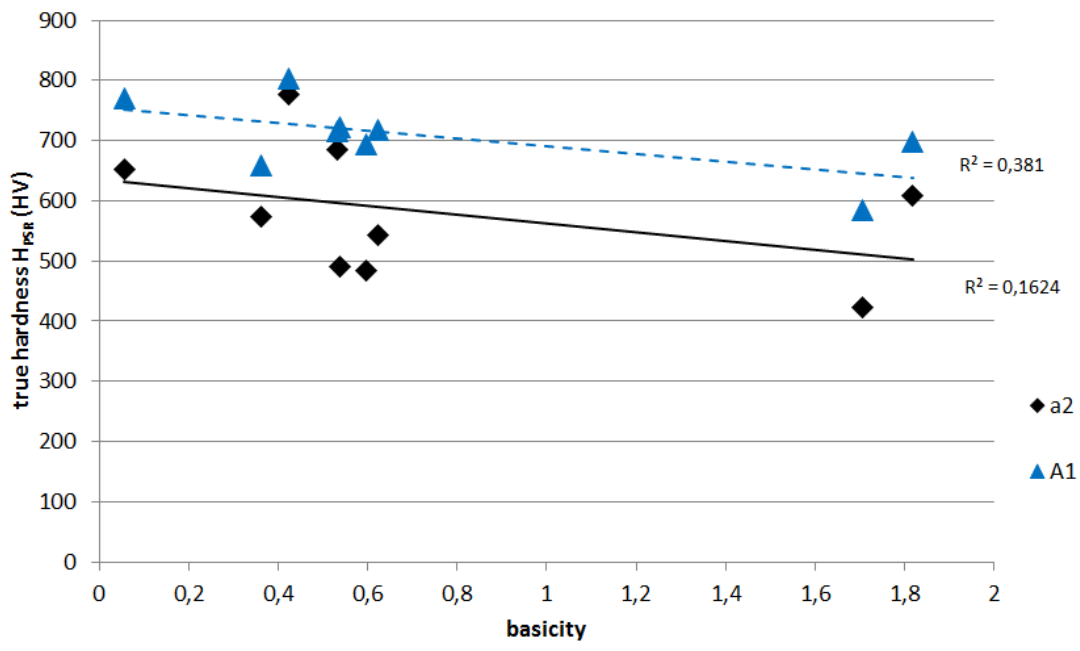

Fig. 6. The relationship between basicity and "true hardness" of the slag. 
In addition to the difference in chemical composition and consequential crystalline texture, the morphology, different cooling rate, the age of samples, the uncertainty in measurement could be the reason for the variance in the measured values of microhardness and ISE.

In the next, the research would be appropriate to focus on the relationship between micro-hardness (and in particular true hardness) and grindability (for example, the influence of the micro-hardness on the grindability index or grinding resistance).

\section{Conclusion}

1. The influence of the load on the micro-hardness of the slag is statistically significant.

2. The relationship between the applied load and micro-hardness manifests "normal" ISE for all tested samples.

3. The relationship between $\mathrm{c}_{0}$ (the residual stress) and $\mathrm{c}_{1} / \mathrm{c}_{2}$ ratio (a measure of the stress due to grinding and polishing) is proportional except the hardest slag (sample No. 6).

4. The presence of wollastonite and diopside does not have a significant effect on the micro-hardness and ISE.

5. The increasing of the basicity moderate decreases Meyer's index $\mathrm{n}$ (towards to "normal" ISE).

6. Due to the significant increase in hardness at lower loads, the authors recommend not to use a load lower than $0.6 \mathrm{~N}$ if the porosity of the sample allows.

\section{Acknowledgements}

This work was supported by the Slovak Grant Agency for Science under Grant VEGA 1/0073/17.

\section{References}

[1] W. Ling, T. Pei, Y. Yan, Application of ground granulated blast furnace slag in high-performance concrete in China: International Workshop on Sustainable Development and Concrete Technology, Beijing, 2004, 309-317.

[2] Mineral Commodity Summaries, Iron and Steel Slag Statistics and Information 2012, https://minerals.usgs.gov/minerals/pubs/commodity/iron_\&_steel_slag/mcs2012-fesla.pdf (accessed: Sept 2017).

[3] Mineral Commodity Summaries, Iron and Steel Slag Statistics and Information 2000. https://s3-us-west-2.amazonaws.com/prd-wret/assets/palladium/production /mineral-pubs/iron-steel-slag/790400.pdf (accessed: Sept 2017).

[4] V. Veselská, J. Majzlan: Environ Sci Polut R, 23 (2016) 7308-7323.

[5] F. Michalíková, V. Jacko, M. Sisol, L. Kozáková: Acta Montanistica Slovaca, 10 (1) (2005) 91-96. (in Slovak)

[6] J. Legemza, Š. Majerčák: Acta Metallurgica Slovaca, 7 (2001) 113-116.

[7] A. Ene, A. Pantelică: Rom J Phys, 7 (2011) 1011-1018.

[8] Pribulová, P. Futaš, D. Baricová: Production engineering archives, 11(2) (2016) 2-5.

[9] G. Bulut: Waste Manag Res, 24 (2006) 1-7.

[10] Y. Li, H.H. Sun, X. M. Liu: Sci China Ser E - Tech Sci. 52 (2009) 2695-2699. 
[11] U.S. Federal Highway Administration Research and Technology, User Guidelines for Waste and Byproduct Materials in Pavement Construction 2016, 139-140 https://www.fhwa.dot.gov/publications/research/infrastructure/structures/97148/t oc.cfm (accessed: Oct 2017).

[12] A.Y. Ilyushechkin, D.G. Roberts, D. French, D.J. Harris, IGCC Solids Disposal and Utilisation, final report for ANLEC project 5-0710-0065. Common wealth Scientific and Industrial Research Organisation, (CSIRO), Australia 2012.

[13] D. Betancourt, D. Chicot, S. Kossman, G. Louis, F. D. Roudet: Constr Build Mater 199 (2019) 349-358.

[14] G. Wang, Ph.D. Thesis, Properties and utilization of steel slag in engineering applications, The University of Wollongong 1992. http://ro.uow.edu.au/cgi/ viewcontent.cgi?article=2258\&context=theses, 1992 (accessed 30 October 2017).

[15] Z. Liu, Y. Zong, H. Ma, W. D. Dai: Adv Appl Ceram, 113 (7) (2014) 394-403.

[16] K. Sangwal: Mater Chem Phys, 63 (2) (2000) 145-152.

[17] A. Abu El-Fadl, A. Soltan, N. Shaalan: Cryst Res Technol 42 (4) (2007) 364-377.

[18] K. Sangwal, B. Surowska, P. Błaziak: Mater Chem Phys, 77(2) (2003) 511-520.

[19] C. Chuenarrom, P. Benjakul, P. Daosodsai: Mat Res, 12 (4) (2009) 473-476.

[20] J. Petrík: Arch Metall Mater, 61 (2016) 1819-1824.

[21] J. Gong, J. Wu, Z. Guan: J Eur Ceram Soc, 19 (1999) 2625-2631.

[22] X. Ren, R. Hooper, C. Griffiths: Mater Sci Lett, 22 (2003) 1105-1106.

[23] ISO 6507-2, Metallic materials. Vickers hardness test. Part 2: Verification and calibration of testing machines, Brussels, EU 2018.

[24] ISO 6507-1, Metallic materials. Vickers hardness test. Part 1: Test method. Brussels, EU 2018.

[25] H. Li, R. Bradt: J Mater Sci, 28 (1993) 917-926.

[26] B. Michels, G. Frischat: J Mater Sci, 17 (1982) 329-334.

[27] H. Kim, T. Kim: J Eur Ceram Soc, 22 (2002) 1437-1445.

[28] J. Petrik, P. Palfy: Metrol Meas Syst, 18(2) (2011) 223-234.

[29] G. Agarwal: J Non-Cryst Solids, 130 (1991) 187-197.

[30] C. Fredericci: J Non-Cryst Solids, 273 (2000) 64-75.

[31] J. Ostrowski: J. Rzechuła, J Non-Cryst Solids, 64 (1984) 334-441.

[32] S. R. Teixeira: A. E. Souza, C. L. Carvalho, V. C. S. Reynoso, M. Romero, J. Ma. Rincón: Mater Charact, 98 (2014) 209-214.

[33] M. M. Smedskjaer, M. Jensen, Y. Z. Yue: J Am Ceram Soc, Section of Chemistry. 91(2) (2008) 514-518.

[34] M. Takeda, T. Onishi, S. Nakakubo, S. Fujimoto: Mater Trans, 50 (2009) 22422246.

\section{(c) (†) Creative Commons License}

This work is licensed under a Creative Commons Attribution 4.0 International License. 